\title{
PIKKUKESKOSENA SYNTYNEIDEN LASTEN YMMÄRRETYN SANASTON KEHITYS VUODEN IÄSSÄ JA SEN YHTEYS KOGNITIIVISEEN KEHITYKSEEN KAKSIVUOTIAANA
}

\author{
Pauliina Alatalo, Oulun yliopisto ja HABS kuntoutus \\ rehabilitering Oy \\ Petriina Munck, Turun yliopistollinen keskussairaala \\ ja Helsingin yliopisto \\ Helena Lapinleimu, Turun yliopistollinen keskussairaala \\ ja Turun yliopisto \\ Suvi Stolt, Helsingin yliopisto
}

\begin{abstract}
Pikkukeskosena (syntymäpaino $<1500 \mathrm{~g} \mathrm{ja/tai} \mathrm{syntynyt}<32$ raskausviikolla) syntyneiden lasten varhaisen ymmärretyn sanaston kehitystä on tutkittu vähän, ja ymmärretyn sanaston ja myöhemmän kognitiivisen kehityksen välistä mahdollista yhteyttä ei tietääksemme ollenkaan. Tämän tutkimuksen tavoitteena oli saada lisää tietoa pikkukeskosena syntyneiden lasten varhaisen ymmärretyn sanaston koosta ja koostumuksesta sekä tutkia varhaisen ymmärretyn sanaston ja myöhemmän kognitiivisen kehityksen välistä yhteyttä. Tähän rekisteritutkimukseen otettiin mukaan ne vuosina 2007-2009 Turun yliopistollisessa keskussairaalassa pikkukeskosena syntyneet lapset $(\mathrm{N}=57)$, joilta oli saatavilla Varhaisen kommunikaation ja kielen kehityksen arviointimenetelmän avulla kerätty tieto ymmärretyn sanaston kehityksestä yksivuotiaana sekä Bayley III -testin avulla arvoitu tieto lapsen kognitiivisesta kehityksestä kaksivuotiaana. Pikkukeskosten ymmärretyn sanaston koko oli pienempi kuin tutkimuksessa käytetyn arviointimenetelmän normiaineiston. Ymmärretyn sanaston koostumuksen kehitys oli edennyt suhteessa sanaston määrälliseen kehitykseen vastaten aiemmin raportoituja tuloksia. Varhaisen ymmärretyn sanaston (koko, koostumus) ja myöhemmän kognitiivisen kehityksen välillä todettiin merkitsevä positiivinen yhteys. Tulokset puoltavat varhaisen ymmärretyn sanaston kehityksen tutkimista osana pikkukeskosten kehitysseurantaa.
\end{abstract}

Avainsanat: kognitiivinen kehitys, pikkukeskonen, sanaston koko, sanaston koostumus, ymmärretty sanasto

\footnotetext{
Kirjoittajan yhteystiedot:

Pauliina Alatalo

pauliina.k.alatalo@gmail.com
}

\section{JOHDANTO}

Lapsi alkaa omaksua kieltä varhaisessa vaiheessa, kun ymmärrys ympäröivästä maailmasta on vielä puutteellista (Perlovsky, 2013). Sanaston omaksuminen alkaa tyypillisesti reseptiivisen 
eli ymmärretyn sanaston kehityksellä ensimmäisen ikävuoden loppupuolella, noin kahdeksan, yhdeksän kuukauden iässä (Bates ym., 1994; Lyytinen, 1999; Stolt, Haataja, Lapinleimu \& Lehtonen, 2008). Ymmärrettyä sanastoa omaksuessaan lapselta vaaditaan kykyä erotella kuulonvaraisesti omaksuttava sana aikuisen puheesta ja yhdistää se sanan viittauskohteeseen (Bates ym., 1994). Kognitiivisella kehityksellä tarkoitetaan tiedonkäsittelyyn, kuten ajatteluun, havaitsemiseen, oppimiseen, muistiin, syy-seuraussuhteiden havaitsemiseen liittyviä asioita sekä ongelmatilanteiden ratkaisemiseen käytettäviä taitoja (Lyytinen, 2000; Nurmi ym., 2006, s. 19). Lapsen varhaisen kielen kehityksen ja kognitiivisen kehityksen välistä suhdetta on tutkittu jonkin verran täysiaikaisena syntyneillä lapsilla (esim. Lyytinen, 1999), mutta keskosaineistoista tähän aiheeseen liittyvät tutkimukset puuttuvat. Tämän tutkimuksen tavoitteena on tutkia pikkukeskosena (syntynyt $<32$. raskausviikkoa ja/tai syntymäpaino $<1500 \mathrm{~g}$ ) syntyneiden lasten varhaisen ymmärretyn sanaston kehitystä ja sen mahdollista yhteyttä lapsen myöhempään kognitiiviseen kehitykseen.

\section{Varhaisen ymmärretyn sanaston koko ja koostumus}

Sana lasketaan ymmärretyksi lapsen antaessa sille selkeän, välittömän ja oikean responssin toistuvasti (Benedict, 1979). Ymmärretyn sanaston kehitys on yleensä alusta alkaen melko aktiivista siten, että täysiaikaisena syntyneillä suomea omaksuvilla lapsilla ymmärretyn sanaston koko on vuoden iässä keskimäärin lähes 90 sanan kokoinen (Lyytinen, 1999; Stolt ym., 2008). Tytöt etenevät varhaisen sanaston kehityksessään ryhmätasolla tarkastellen keskimäärin hieman nopeammin kuin pojat, vaikkakin yksilölliset erot sanaston omaksumisessa ovat suuria (Fenson ym.
1994, Lyytinen, 1999; Stolt ym., 2008).

Sanaston koostumuksella viitataan siihen, mitä sanaluokan sanoja lapsen sanasto sisältää ja mikä on niiden suhteellinen osuus kehittyvässä sanastossa (Bates ym., 1994). Varhaisen sanaston koostumuksen kehitys vaikuttaisi tutkimusten mukaan noudattavan ryhmätasolla tarkastellen säännönmukaisia kehityskulkuja omaksuttavasta kielestä riippumatta (Caselli ym., 1995; Caselli, Casadio \& Bates, 1999; Stolt ym., 2017).

Koostumuksen kehityksen on todettu olevan sidoksissa sanaston määrälliseen kehitykseen (Caselli ym., 1995; Caselli ym., 1999; Stolt ym., 2017). Lapsen varhainen, enintään noin 50 sanaa kattava sanasto koostuu yleensä pitkälti niin kutsutuista sosiaalis-pragmaattisista sanoista, joita ovat onomatopoeettiset äännähdykset, lapsen arkeen vahvasti kytkeytyviin rutiinitoimintoihin liittyvät sanat ja vanhempien nimet (Bates ym., 1994; suomea omaksuvilla lapsilla Stolt ym., 2008). Ensimmäisten sanojen joukossa on usein runsaasti myös substantiiveja. Substantiivien, kuten asioiden ja esineiden nimien, osuus on erityisen suuri noin 50-200 sanan sanastoissa, mutta tätä suuremmissa sanastoissa niiden suhteellinen osuus pienenee. Verbien ja adjektiivien omaksuminen on hitaampaa, niitä opitaan tasaisesti sanaston koon kasvaessa. Kun lapset ovat saavuttaneet noin 300-500 sanan sanavaraston, he alkavat yhä aktiivisemmin omaksua niin kutsuttuja sulkeisen luokan sanoja, kuten prepositioita, pronomineja, kysymyssanoja, konjunktioita ja määrää ilmaisevia sanoja (Bates ym., 1994; suomea omaksuvilla lapsilla Stolt ym., 2008). Kuvatun tyyppiset kehityspolut näyttäisivät olevan pitkälti samanlaisia sekä ymmärretyssä että ilmaistussa sanastossa (Benedict, 1979; Caselli ym., 1995; Stolt ym., 2008; Stolt, Haataja, Lapinleimu \& Lehtonen, 2009), vaikkakin lapset vaikuttavat omaksuvan verbejä hieman aktiivisemmin varhaisiin ymmärrettyihin sanastoihinsa 
ilmaistuihin verrattuna (Benedict, 1979; Caselli ym., 1995; Stolt ym., 2008).

Keskosena syntyneillä lapsilla on osoitettu olevan ryhmätasolla arvioiden hitaampi ymmärretyn sanaston kehitys sekä kokoa (Cattani ym., 2010; Menyuk, Liebergott, Schultz, Chesnick \& Ferrier, 1991; Riitesuo, 2000; Sansavini ym., 2011; Stolt ym., 2009) että koostumusta (Sansavini ym., 2011; Stolt ym., 2009) tarkastellen kuin täysiaikaisena syntyneillä lapsilla. Esimerkiksi aiemmassa suomalaisessa pitkittäisseurantatutkimuksessa (Stolt ym., 2009) pikkukeskosten ( $N=32$, sp $\leq 1500$ $\mathrm{g}$, lasten keskimääräinen gestaatioikä 28 raskausviikkoa, vaihteluväli 23-34 raskausviikkoa), ymmärretyn sanaston keskimääräinen koko oli vuoden korjatussa iässä 56 sanaa, eli merkitsevästi pienempi kuin täysiaikaisina syntyneiden verrokkien ( $\mathrm{N}=35)$, joilla vastaava arvo oli 94 sanaa. Korjatulla iällä tarkoitetaan raskauden alkuvaiheessa määritetystä nk. lasketusta ajasta laskettua lapsen ikää, ei varsinaisesta syntymäpäivästä laskettua ikää (Blackmon ym., 2004). Ymmärretyn sanaston koostumuksen kehitys vastasi kuitenkin lähes täysin täysiaikaisena syntyneiden lasten sanaston koostumuksen kehitystä, kun kehitys suhteutettiin sanaston kokoon (Stolt ym., 2009). Keskosena syntyneiden lasten varhaista ymmärretyn sanaston kehitystä on kuitenkin tutkittu vasta vähän ja tutkittujen lasten määrät ovat olleet pienehköjä. Aiheesta tarvitaan siis lisää tietoa.

\section{Varhainen kognitivinen kehitys ja kielen kehityksen yhteys kognitiviseen kehitykseen}

Lapsi hankkii tietoa ympäristöstään ja oppii kognition avulla (Nurmi ym., 2006, s. 20). Jo vastasyntyneellä on valmiudet havaitsemiseen, muistamiseen ja siten oppimiseen. Vauvan kasvaessa kehittyvät myös ongelmanratkaisutaidot, joissa yhdistyvät muistin ja päättelyn taidot (Salo, Munck \& Korja, 2008). Esimerkiksi kaksivuotias lapsi löytää esineen, vaikka sen paikkaa olisi vaihdettu. Muistin kehittymistä toisen ikävuoden aikana kuvaa pysyvien mielikuvien ja sellaisten kohteiden jäljittely, jotka eivät ole läsnä (Lyytinen, 2000). Tyypillisesti toiseen ikävuoteen mennessä lapset alkavat myös leikkiä leikkejä, jotka sisältävät kuvitteellisuutta tai mielikuvia (Salo ym., 2008). Lapsen kehityksen myötä symbolinen leikki monipuolistuu ja esimerkiksi kolmevuotias lapsi puhuu jo leikisti leikkipuhelimeen. Syy-seuraussuhteiden ja analogiapäättelyn ensimmäisiä merkkejä ilmenee noin 6-7 kuukauden ikäisillä lapsilla (Nurmi ym., 2006, s. 25-26). Pienten lasten analogiapäättely pohjautuu havaintojen kautta saatuun tietoon, kun taas kielelliset ja käsitteelliset perusteet tukevat vahvemmin isompien lasten päättelyä.

Keskoset ovat kognitiiviselta kehitykseltään heterogeeninen ryhmä (esim. PyhäläNeuvonen, Nyman \& Korja, 2017). Vaikka osa pikkukeskosista kehittyy ikäodotusten mukaisesti, on tähän ryhmään kuuluvilla lapsilla kohonnut riski kognitiivisen kehityksen vaikeuksille täysiaikaisena syntyneisiin lapsiin verrattuna (Munck ym., 2010). Riski kognitiivisiin kehityshäiriöihin kasvaa sitä suuremmaksi, mitä aiemmin lapsi on syntynyt ja mitä pienempi lapsen syntymäpaino on (FoulderHughes \& Cooke, 2003; ks. myös Bode ym., 2009; Munck ym., 2010; Woodward, Anderson, Austin, Howard \& Inder, 2006). Esimerkiksi Toome ym. (2013) havaitsivat, että virolaisten pikkukeskosena syntyneiden ( $\mathrm{n}=155,<32$ rv.) lasten kognitiivinen kehitys oli kahden vuoden korjatussa iässä merkitsevästi heikompaa ryhmätasolla arvioiden kuin täysiaikaisina syntyneiden verrokkien. Keskosista 12 \%:lla oli lievä kognitiivisen kehityksen viive, kolmella prosentilla keskivaikea ja kahdella prosentilla vaikea kognitiivisen kehityksen viive. 
Varhaisen kielen kehityksen ja kognitiivisen kehityksen yhteyttä on tutkittu erityisesti täysiaikaisena syntyneillä lapsilla (esim. Lyytinen, 1999) ja lähinnä liittyen ilmaistun kielen ja kognition kehityksen väliseen yhteyteen. Löydökset osoittavat, että ainakin toisen ikävuoden lopulla ilmaistun sanaston kehitys ja kognitiivinen kehitys ovat merkitsevässä positiivisessa yhteydessä keskenään sekä täysiaikaisena että pikkukeskosena ( $\mathrm{sp}<1500$ g) syntyneiden lasten aineistossa (esim. Stolt ym., 2007). Mossabeb, Wade, Finnegan, Sivieri ja Abbasi (2012) havaitsivat, että raskausviikoilla 23-34 syntyneillä keskosilla kahden vuoden iässä ilmaistun sanavaraston viive oli yhteydessä heikompaan kognitiiviseen suoriutumiseen. Laakson, Eklundin ja Poikkeuksen (2011) tutkimuksessa täysiaikaisina syntyneillä lapsilla puheen ymmärtämisen havaittiin korreloivan vuoden iästä alkaen erittäin merkitsevästi kaksivuotiaana mitattuihin kognitiivisiin ja kielellisiin valmiuksiin. Pelkkä kognitiivisen kehityksen arviointi ei kuitenkaan anna riittävästi tietoa pikkukeskosen kielestä siten, että heikosti kielellisessä kehityksessään etenevä lapsi pystyttäisiin sen perusteella kliinisessä työssä tunnistamaan (Stolt ym., 2014a).

Pikkukeskosena syntyneiden lasten varhaisen ymmärretyn sanaston kehityksen ja myöhemmän kognitiivisen kehityksen välistä yhteyttä ei tietääksemme ole aiemmin tutkittu. Pikkukeskosena ( $\mathrm{sp} \leq 1500 \mathrm{~g})$ syntyneiden lasten vuoden iässä mitatulla ymmärretyn sanaston koolla on kuitenkin osoitettu olevan hyvä ennustearvo lasten kahden vuoden korjatun iän kielelliseen kokonaistasoon (Stolt ym., 2014b). Varhaisen ymmärretyn sanaston koon on myös osoitettu korreloivan merkitsevästi lasten ilmaistun sanaston kehitykseen kahden vuoden korjatussa iässä keskosaineistossa (Sansavini ym., 2011). Olisikin tärkeää tietää, löytyykö vastaava yhteys myös varhaisen ymmärretyn sanaston ja myöhemmän kognitiivisen kehityksen välillä.

Varhaisen ymmärretyn sanaston ja kognition välistä yhteyttä pohdittaessa on tärkeää huomioida, että varhainen ilmaistu ja ymmärretty sanasto eivät välttämättä kehity samassa tahdissa (Bates, Dale \& Thal, 1995). Ilmaistun sanaston kehityksen perusteella ei siis voida tehdä suoraviivaisia päätelmiä lapsen ymmärretyn kielen hallinnasta. Varhaisen ymmärretyn sanaston ja myöhemmän kognitiivisen kehityksen välinen mahdollinen yhteys on kliinisesti kiinnostava ja tärkeä aihe, sillä keskosten kognitiivinen viive pystytään usein kliinisessä työssä tunnistamaan vasta lapsen kehityksen myötä. Laaja-alaiset kognitiivisen kokonaiskehityksen ongelmat pystytään tunnistamaan varsin luotettavasti noin kahden vuoden iässä (Munck ym., 2012). Sen sijaan neuropsykologiset erityisvaikeudet esimerkiksi muistin, toiminnanohjauksen tai oppimisvaikeuksien riskien suhteen ovat osalla lapsista tunnistettavissa vasta noin viiden vuoden iässä (Lind, ym., 2011). Mikäli varhaisen ymmärretyn sanaston kehityksen ja myöhemmän kognitiivisen kehityksen välillä olisi yhteys keskosaineistossa, antaisi se tärkeää tietoa keskosten varhaisvaiheen kehitysseurantaan. Tämä on tärkeää, sillä varhaisilla interventioilla voidaan vaikuttaa myönteisesti keskosena syntyneiden lasten kehitykseen (Orton, Spittle, Doyle, Anderson \& Boyd, 2009). Riskilapsia, kuten varhaisilla gestaatioviikoilla ja/tai pienipainoisena syntyneitä keskosia, olisikin tärkeää tukea mahdollisimman varhain, jotta ongelmien kasautumista pystyttäisiin estämään (Sajaniemi ym., 2001).

Tämän tutkimuksen tavoitteena oli saada lisää tietoa pikkukeskosena (syntymäpaino < $1500 \mathrm{~g} \mathrm{ja}$ /tai syntynyt < 32 raskausviikkoa) syntyneiden lasten ymmärretyn sanaston kehityksestä vuoden korjatussa iässä ja sen mahdollisesta yhteydestä kognitiiviseen kehitykseen kahden vuoden korjatussa iässä. Tutkimuksen tavoitteena oli hakea vastauksia 
seuraaviin kysymyksiin: 1. Millainen on pikkukeskosena syntyneiden lasten ymmärretyn sanaston koko ja koostumus vuoden korjatussa iässä? ja 2. Onko pikkukeskosena syntyneiden lasten vuoden korjatussa iässä mitatulla ymmärretyn sanaston koolla ja koostumuksella yhteyttä kognitiiviseen kehitykseen kaksivuotiaana?

Tämä tutkimus pohjaa Oulun yliopistossa tarkastettuun pro gradu -työhön (Alatalo, 2015). Tutkimus on osa kokonaisuutta " $H y$ vin ennenaikaisina ja/tai hyvin pienipainoisina syntyneiden lasten varhaisen reseptivisen sanaston ja ele-esinetoimintojen kebitys, tämän kehityksen yhteys kognitiviseen kehitykseen kaksivuotiaana sekä kebitykseen vaikuttavat tekijät" (tutkimuksen vastuulliset johtajat: dosentit Suvi Stolt ja Helena Lapinleimu).

\section{TUTKITTAVAT JA MENETELMÄT}

\section{Tutkittavat}

Tämän pitkittäistutkimuksen aineisto on kerätty osana kliinistä kehitysseurantaa Turun yliopistollisessa keskussairaalassa vuosina 2007-2009. Tutkimuksen sisäänottokriteerinä oli, että tutkittavat keskoset painoivat syntyessään < $1500 \mathrm{~g} \mathrm{ja}$ /tai he olivat syntyneet ennen 32. raskausviikkoa. Tutkittavien lasten äidinkieli oli suomi. Aineisto koostuu lapsista, joilta oli saatavilla vuoden korjatussa iässä ymmärretyn sanaston kehitystä koskeva tieto ja kahden vuoden korjatussa iässä kognitiivista kehitystä koskeva tieto. Tässä rekisteritutkimuksessa tietoja vanhempien koulutustasosta ja lapsen syntymäjärjestyksestä mahdollisiin sisaruksiinsa nähden ei ollut saatavilla.

Tutkittavien joukko koostui 57 lapsesta (18 tyttöä, 38 poikaa, yhden sukupuolesta ei merkintää). Lapsista 14 oli syntynyt erittäin pienipainoisena (syntymäpaino $<1000$ g), 27 hyvin pienipainoisena (syntymäpaino $1000-1499$ g) ja 16 lasta pienipainoi- sena (syntymäpaino $\geq 1500 \mathrm{~g}$ ). Näin ollen 41 lapsen syntymäpaino oli < 1500 g. Koko ryhmän keskimääräinen syntymäpaino oli $1251 \mathrm{~g}$ (keskihajonta $366 \mathrm{~g}$, mediaani 1225 g, syntymäpainojen vaihteluväli 600-2120 g). Lasten syntymät ajoittuivat raskausviikoille 24,3-35,0, ja keskimäärin raskaus oli kestänyt 29,4 viikkoa (keskihajonta 2,4 rv, mediaani 29,6 rv.) Tutkimukseen osallistuneista lapsista aivorungon kuuloherätevastetutkimus (BAEP) oli 44 lapsella normaali, kahdella lapsella havaittiin poikkeava löydös ja 11 lapselta tulos puuttui rekisteriaineistosta. Tässä rekisteritutkimuksessa ei ollut täysiaikaisina syntyneistä lapsista koostuvaa verrokkiryhmää tutkittavien tuloksia verrattiin tutkimuksessa käytettyjen normitettujen arviointimenetelmien normipopulaatioiden tuloksiin.

\section{Menetelmät}

Ymmärretyn sanaston tutkimisessa käytettiin Fensonin ym. (1994) kehittämää The MacArthur-Bates Communicative Development Inventories (CDI) -menetelmän suomalaiseen aineistoon muokattua ja normitettua versiota, jonka nimi on 'Varhaisen kommunikaation ja kielen kehityksen arviointimenetelmä' (Lyytinen, 1999). CDI- menetelmään on tutkimuksen perusteella valittu lapsen varhaiselle kielelle tyypillisiä sanoja. Sanat edustavat eri sanaluokkakategorioita (esim. substantiivit, verbit, adjektiivit), ja ne esitetään sanalistojen muodossa. Suomalainen CDI-menetelmän varhaista sanaston kehitystä arvioiva versio, jota tässä tutkimuksessa käytettiin, koostuu yhteensä 380 sanasta. Sanat on jaoteltu 19 eri semanttiseen kategoriaan (Lyytinen, 1999). Suomalaisen CDI-menetelmän normiaineistossa vuoden ikäisillä lapsilla ymmärrettyjen sanojen keskiarvo oli 89 sanaa (keskihajonta 63, mediaani 67, minimi 6 ja maksimi 263 sanaa).

CDI-menetelmä pohjautuu vanhempien 
tekemään arvioon oman lapsensa varhaisesta kielellis-kommunikatiivisesta kehityksestä. Vanhemmat ohjeistettiin merkitsemään ne sanat, jotka heidän lapsensa joko "ymmärtää" (= ymmärretty sanasto) tai "ymmärtää ja sanoo" (= ilmaistu sanasto). Tässä tutkimuksessa tarkastellaan ainoastaan ymmärretyn sanaston kokoa ja koostumusta, koska ilmaistun sanaston koko on vuoden ikäisellä lapsella vielä pieni. Vanhemmat täyttivät CDI-menetelmän 8-16 kuukauden ikäisille suunnatun "Sanat ja eleet" -lomakkeen osana kliinistä seurantaa lapsen ollessa 12 kuukauden korjatussa iässä. CDI-menetelmää käytettäessä lapsi saa kustakin ymmärretystä sanasta yhden pisteen. Lopullinen pistemäärä kuvastaa sanalistoihin sisällytettyjen, lapsen ymmärtämien sanojen kokonaismäärää. CDI-menetelmän validiteetin on todettu olevan hyvä lapsen varhaisia kielellisiä taitoja arvioitaessa (esim. Fenson ym., 2007). Validiteettia lisää se, että vanhempien tekemä arvio ei perustu muistiin vaan arviointihetkellä olevan kehityksen tunnistamiseen, sekä se, että vanhemmille annetaan valmiit sanalistat, joiden perusteella heidän tulee arvionsa tehdä (Fenson ym., 2007).

Kognitiivisen kehityksen tutkimiseen käytettiin Bayley Scales of Infant and Toddler Development -testin suomalaisen laitoksen kognitiivista asteikkoa (BSID III; engl. versio: Bayley, 2006; suom. versio: Salo, Munck \& Korja, 2008). Psykologi arvioi lapsen kognitiivisen kehityksen Bayley III -testin avulla +/-2 viikon kuluessa lapsen kaksivuotissyntymäpäivästä (korjattu ikä). Bayley III -testin kognitiivisen asteikon avulla kartoitetaan lapsen yleisiä päättelyn taitoja. Se sisältää seuraavat osa-alueet: yhdistämis- ja erottelukyky, muistin toiminta, esineiden tarkoituksenmukainen käyttö, osakokonaisuuksien hahmottaminen, käsitteiden ymmärtäminen, numeerinen hallinta, informaation prosessointitaidot, prosessointinopeus sekä symbolinen leikki (Salo ym., 2008).
Bayley III -testiä pisteytettäessä lapsi saa onnistuneesta suorituksesta yhden pisteen (Salo ym., 2008). Raakapistemäärä koostuu hyväksytysti suoritettujen osioiden pisteiden summasta sekä varhaisempien kehitysvaiheiden pistemääristä, sillä lapsen oletetaan jo hallitsevan nämä taidot. Raakapistemäärä muunnetaan standardipisteiksi käsikirjan osoittamalla tavalla. Standardipisteiden avulla voidaan tarkastella lapsen suoriutumista suhteessa ikään (Salo ym., 2008). Standardipisteiden keskiarvo on kymmenen pistettä, vaihteluväli 1-19 pistettä ja keskihajonta kolme pistettä. Bayley III testin amerikkalaisten normien toimivuus on tarkistettu suomalaisella otannalla.

\section{Aineiston analysointi}

Jokaiselta lapselta laskettiin ensin ymmärrettyjen sanojen kokonaismäärä. Tämän jälkeen laskettiin kullekin lapselle ymmärretyssä sanastossa olevien eri semanttisiin sanaluokkakategorioihin sisältyvien ymmärrettyjen sanojen määrät. Tässä luokittelussa käytettiin Batesin ja ryhmän (1994; ks. myös Stolt ym., 2008) jaottelua (so. sosiaalispragmaattiset sanat, substantiivit, verbit, adjektiivit sekä sulkeisen luokan sanat). Sosiaalis-pragmaattisiin sanoihin kuuluivat onomatopoeettiset äännähdykset, vanhempien nimet ja rutiinitoimintoihin liittyvät sanat. Substantiivit olivat esineiden ja asioiden nimiä. Sulkeisen luokan sanat pitivät sisällään pronominit, kysymyssanat, prepositiot ja määrän ilmaisut. Lisäksi käytettiin kategoriaa "muut sanat", johon sisällytettiin, Batesin ja ryhmän (1994) jaottelun mukaisesti (ks. myös Caselli ym., 1999), ne varhaiset lapsen kielen sanat, jotka sisältyivät CDImenetelmään, mutta joita ei voitu luokitella em. ryhmiin (so. luontoon ja lähiympäristöön liittyvät sanat sekä aikaan liittyvät sanat).

Ymmärretyn sanaston kokoa tarkasteltiin kuvailevien lukujen (keskiarvo, keskihajonta, minimi, maksimi) avulla. Lisäksi tutkittiin, 
kuinka monella aineiston keskosista ymmärretyn sanaston koko oli $\leq 17$ sanaa (heikoimman $10 \%$ :n persentiiliarvo Varhaisen kommunikaation ja kielen kehityksen arviointimenetelmän täysiaikaisena syntyneiden lasten normiaineistossa; Lyytinen, 1999; henkilökohtainen tiedonanto sähköpostitse K. Eklundilta S. Stoltille 6.2.2017) vuoden korjatussa iässä.

Sanaston koostumuksen tutkimiseksi ymmärretyssä sanastossa olevien eri sanaluokkakategorioihin kuuluvien sanojen määriä ja osuuksia tarkasteltiin aluksi kuvailevien lukujen avulla ryhmätasolla. Jokaiselle lapselle laskettiin lisäksi edellä mainittuihin sanaluokkakategorioihin kuuluvien sanojen prosentuaaliset osuudet sanastossa lapsen omaksumien ymmärrettyjen sanojen kokonaismäärästä. Ymmärretyt sanastot jaettiin alaryhmiin ymmärrettyjen sanojen kokonaismäärän perusteella (1-9 sanan sanastot, $\mathrm{n}=7$ lasta; $10-49$ sanaa, $\mathrm{n}=25 ; 50-99$ sanaa, $\mathrm{n}=10$; yli 100 sanaa, $\mathrm{n}=15$; esim. Caselli ym., 1995; Stolt ym., 2009), ja kussakin sanastokokoluokassa tarkasteltiin sosiaalispragmaattisten sanojen, substantiivien, verbien, adjektiivien ja sulkeisen luokan sanojen prosentuaalisten osuuksien kuvailevia lukuja.

Sanaston koon ja koostumuksen (sanojen määrät ja prosentuaaliset osuudet sanastossa) sekä myöhemmän kognitiivisen kehityksen välistä yhteyttä tutkittiin aluksi Spearmannin korrelaatiokertoimen avulla. Varhaisen ymmärretyn sanaston ennustearvoa myöhempään kognitiiviseen kehitykseen tutkittiin lineaarisen regressioanalyysin avulla. Tässä analyysissa selitettävänä muuttujana oli kognitiivinen kehitys 2-vuotiaana (standardipisteet), ja selittävinä muuttujina olivat ymmärretyn sanaston koko vuoden iässä ja syntymäpaino. Selittävät muuttujat laitettiin malliin yhtä aikaa. Koska ymmärretyn sanaston koon residuaalit eivät jakautuneet normaalisti, tehtiin logaritmimuunnos (Metsämuuronen, 2006, s. 659). Lapset jaettiin lisäksi kolmeen alaryhmään kahden vuoden iän kognitiivisen kehityksen perusteella (so. tyypillinen kognitiivinen kehitys, vähintään 8 standardipistettä, $S P, n=50$; lievä viive, 6-7 SP, $n=4$; huomattava kognitiivinen viive, $<6$ SP, $n=3$ ), ja eri alaryhmiin kuuluvien lasten varhaisen ymmärretyn sanaston kehitystä tarkasteltiin erikseen kuvailevien lukujen avulla.

Syntymäpainon ja kognitiiviseen kehityksen mahdollista yhteyttä tarkasteltiin Spearmannin korrelaatiokertoimen avulla. Aineiston analysointi tehtiin IBM SPSS Statistics 22 -ohjelman avulla. Tilastollisen merkitsevyyden (p) raja-arvona pidettiin arvoa 0,05.

\section{TULOKSET}

\section{Ymmärretyn sanaston koko ja koostumus korjatussa vuoden iässä}

Pikkukeskosten ymmärrettyjen sanojen keskiarvo vuoden korjatussa iässä oli 66 sanaa, ja erot omaksuttujen sanojen määrissä olivat lasten välillä hyvin suuria (keskihajonta, kh, 61, mediaani, md, 42, minimi, min., 0, maksimi, maks. 261 sanaa; menetelmän normiaineisto: ka 89, kh 63, md 67, min. 6, maks. 263). Viidellätoista (26\%) keskosella ymmärretyn sanaston koko oli $\leq 17$ sanaa vuoden korjatussa iässä. Vastaava osuus käytetyn menetelmän täysiaikaisena syntyneiden lasten normiaineistossa on $10 \%$ (Lyytinen, 1999; henkilökohtainen tiedonanto sähköpostitse K. Eklundilta S. Stoltille 6.2.2017).

Ensimmäisten ymmärrettyjen sanojen joukossa oli määrällisesti eniten sosiaalispragmaattisia sanoja ja substantiiveja (Taulukko 1). Verbien, adjektiivien, sulkeisen luokan sanojen ja niin sanottujen muiden sanojen määrä oli vähäisempi. Lasten välillä oli huomattavan suuria eroja siinä, kuinka paljon ja minkä tyyppisiä sanoja he olivat varhaiseen ymmärrettyyn sanastoonsa omaksuneet. 
Taulukko 1. Ymmärretyn sanaston koostumus vuoden korjatussa iässä. Taulukossa ilmoitetaan eri semanttisiin sanaluokkakategorioihin sisältyneiden sanojen määrien kuvailevat luvut.

\begin{tabular}{|l|l|l|l|l|l|}
\hline & Keskiarvo & Keskihajonta & Mediaani & Minimi & Maksimi \\
\hline $\begin{array}{l}\text { Sosiaalis- } \\
\text { pragmaattiset } \\
\text { sanat }\end{array}$ & 16 & 9 & 12 & 0 & 39 \\
\hline Substantiivit & 30 & 31 & 17 & 0 & 118 \\
\hline Verbit & 11 & 12 & 8 & 0 & 48 \\
\hline Adjektiivit & 3 & 5 & 1 & 0 & 22 \\
\hline $\begin{array}{l}\text { Sulkeisen luokan } \\
\text { sanat }\end{array}$ & 4 & 5 & 1 & 0 & 19 \\
\hline Muut sanat & 3 & 4 & 1 & 0 & 19 \\
\hline
\end{tabular}

Taulukko 2. Eri semanttisiin sanaluokkakategorioihin sisältyneiden sanojen prosentuaaliset osuudet ymmärretyssä sanastossa vuoden korjatussa iässä. Prosentuaaliset osuudet laskettiin kullekin lapselle omaksuttujen ymmärrettyjen sanojen kokonaismäärästä.

\begin{tabular}{|l|l|l|l|l|l|}
\hline & Keskiarvo & Keskihajonta & Mediaani & Minimi & Maksimi \\
\hline $\begin{array}{l}\text { Sosiaalis- } \\
\text { pragmaattiset } \\
\text { sanat }\end{array}$ & 35 & 19 & 29 & 0 & 89 \\
\hline Substantiivit & 38 & 18 & 42 & 0 & 70 \\
\hline Verbit & 15 & 10 & 17 & 0 & 36 \\
\hline Adjektiivit & 3 & 4 & 2 & 0 & 17 \\
\hline $\begin{array}{l}\text { Sulkeisen luokan } \\
\text { sanat }\end{array}$ & 4 & 4 & 4 & 0 & 14 \\
\hline Muut sanat & 3 & 3 & 2 & 0 & 11 \\
\hline
\end{tabular}

Tarkasteltaessa ymmärrettyjen sanastojen koostumusta koko aineistossa prosentuaalisten osuuksien avulla todettiin, että sekä substantiivien että sosiaalispragmaattisten sanojen osuudet sanastoissa olivat huomattavan suuria (Taulukko 2). Verbien osuus oli kolmanneksi suurin, ja adjektiivien, sulkeisen luokan sanojen sekä nk. muiden sanojen prosentuaaliset osuudet olivat vähäisempiä. Syntymäpainolla ei havaittu olevan yhteyttä sanaston kokoon $(\mathrm{r}=0.05, p=0.70)$ eikä koostumukseen $(\mathrm{r}=-0.10-0.10, p=0.44-0.74)$.

Kun tarkasteltiin ymmärrettyihin sanastoihin sisältyvien sanojen osuuksia sanastokokoluokittain, todettiin seuraavat kehityspolut (Taulukko 3, Kuvio 1). Aivan pienissä, 1-9 sanan, ymmärretyissä sanastoissa sosiaalis-pragmaattisten sanojen prosentuaalinen osuus kokonaissanamäärästä oli hyvin suuri, mutta näiden sanojen osuus laski huomatta- 
vasti sanaston koon kasvaessa. Substantiivien osuus oli 1-9 ja 10-49 sanan sanastoissa kohtalainen, ja niiden osuus kasvoi huomattavasti sanaston määrällisen kehityksen myötä ollen $>100$ ymmärretyn sanaston sanastoissa miltei
$50 \%$. Verbien osuus oli kohtuullisen suuri pienissäkin ymmärretyissä sanastoissa: jo 10-49 sanan kokoisissa ymmärretyissä sanastoissa se oli $17 \%$. Verbien osuus säilyi samantyyppisenä myös tätä suuremmissa ymmärretyissä sa-

Taulukko 3. Eri semanttisiin sanaluokkakategorioihin kuuluvien ymmärrettyjen sanojen osuudet sanastokokoluokittain. Taulukossa ilmoitetaan ymmärrettyyn sanastoon sisältyvien erityyppisten sanojen prosentuaalisten osuuksien keskiarvo ja keskihajonta kussakin sanastokokoluokassa. Prosentuaaliset osuudet laskettiin kullekin lapselle omaksuttujen ymmärrettyjen sanojen kokonaismäärästä.

\begin{tabular}{|l|l|l|c|c|c|c|}
\hline $\begin{array}{l}\text { Sanasto- } \\
\text { koko- } \\
\text { luokka }\end{array}$ & $\begin{array}{l}\text { Sosiaalis- } \\
\text { pragmaattiset } \\
\text { sanat }\end{array}$ & Substantiivit & Verbit & Adjektiivit & $\begin{array}{l}\text { Sulkeisen } \\
\text { luokan sanat }\end{array}$ \\
\hline $1-9$ & Keskiarvo & 62 & 13 & 5 & 2 & 3 \\
$(n=7)$ & Keskihajonta & 31 & 18 & 10 & 4 & 6 \\
\hline $10-49$ & Keskiarvo & 40 & 36 & 17 & 2 & 3 \\
$(n=25)$ & Keskihajonta & 12 & 17 & 13 & 4 & 4 \\
\hline $50-99$ & Keskiarvo & 25 & 45 & 17 & 4 & 6 \\
$(n=10)$ & Keskihajonta & 5 & 8 & 4 & 2 & 4 \\
\hline$\geq 100$ & Keskiarvo & 19 & 49 & 16 & 6 & 6 \\
$(n=15)$ & Keskihajonta & 4 & 9 & 6 & 3 & 4 \\
\hline
\end{tabular}

Kuvio 1. Pikkukeskosena syntyneiden lasten ymmärretyn sanaston koostumus vuoden korjatussa iässä. Kuviossa ilmoitetaan sosiaalis-pragmaattisten sanojen, substantiivien, verbien, adjektiivien ja sulkeiseen luokkaan kuuluvien sanojen prosentuaalisten osuuksien keskiarvo kussakin sanastokokoluokassa.
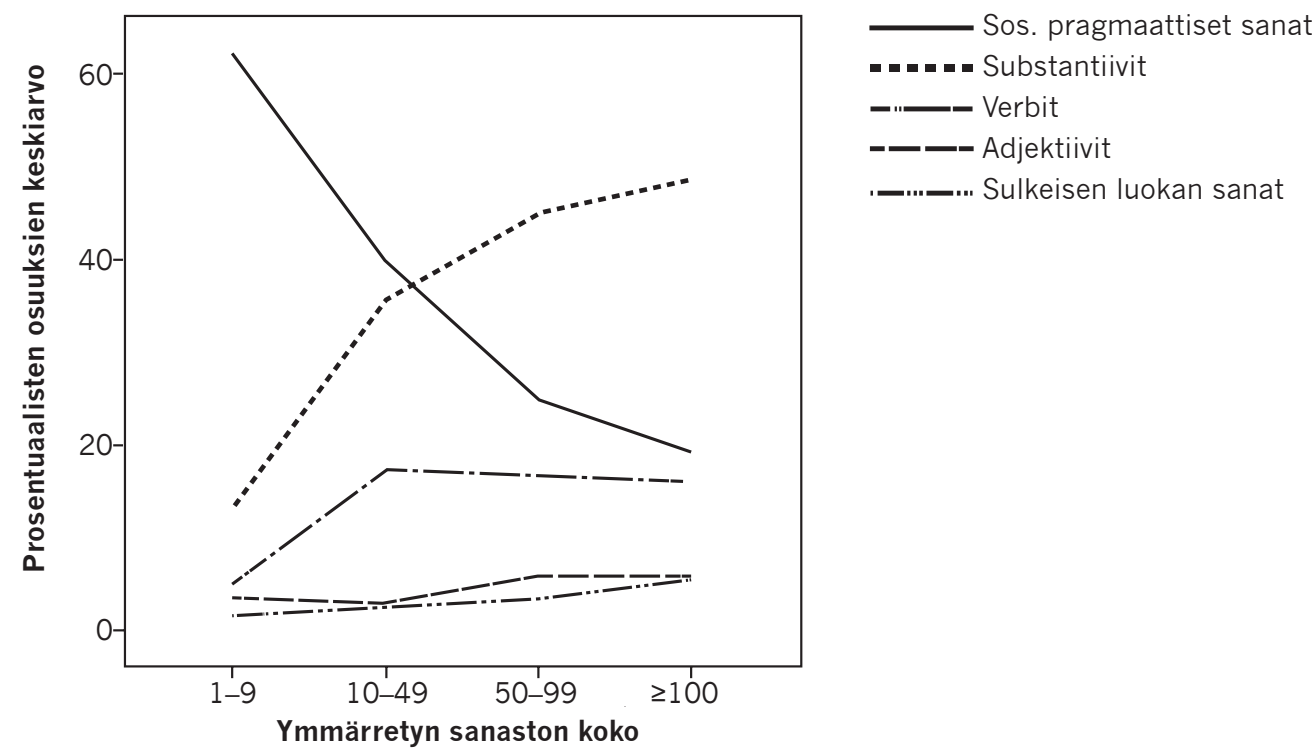
nastoissa. Adjektiivien ja sulkeiseen luokkaan kuuluvien sanojen osuudet kasvoivat tasaisesti vähitellen lasten omaksuessa lisää sanoja ymmärrettyyn sanastoonsa.

\section{Varhaisen ymmärretyn sanaston ybteys kognitiviseen kehitykseen kaksivuotiaana}

Pikkukeskosten kognitiivisten standardipis- teiden keskiarvo oli kahden vuoden korjatussa iässä kymmenen pistettä (kh 3, md 11, min. 3, maks. 15 pistettä), mikä vastaa testin normiaineiston keskiarvoa sekä jakaumaa. Keskosten saamat kognitiiviset standardipistemäärät on esitelty tarkemmin taulukossa 4 (vrt. Salo ym., 2008, s. 47). Syntymäpainolla ei havaittu olevan tilastollisesti merkitsevää yhteyttä kognitiiviseen kehitykseen $(\mathrm{r}=-0.15, p=0.26)$.

Taulukko 4. Keskosten kognitiivisen kehityksen standardipistemäärät kahden vuoden korjatussa iässä.

\begin{tabular}{|l|c|c|}
\hline Kognitiivinen standardipistemäärä & Lasten määrä (n) & $\%$ \\
\hline Erittäin hyvä (17-19 p.) & 0 & 0 \\
\hline Selvästi yli keskitason (15-16 p.) & 2 & 4 \\
\hline Vähän yli keskitason (13-14 p.) & 9 & 16 \\
\hline Keskitasoa (8-12 p.) & 2 & 68 \\
\hline Vähän alle keskitason (6-7 p.) & 3 & 4 \\
\hline Selvästi alle keskitason (4-5 p.) & 2 & 5 \\
\hline Erittäin heikko (1-3 p.) & 39 & 4 \\
\hline
\end{tabular}

p. = pistettä

Varhaisen ymmärretyn sanaston koon ja myöhemmän kognitiivisen kehityksen välillä oli tilastollisesti merkitsevä positiivinen yhteys $(\mathrm{r}=0.33$, $p=0.01$; Kuvio 2$)$. Toisen muuttujan pistemäärän kasvaessa myös toisen muuttujan pistemäärä kasvoi. Tarkasteltaessa varhaisen ymmärretyn sanaston ennustearvoa myöhempään kognitiiviseen kehitykseen nähden lineaarisen regressioanalyysin avulla, todettiin, että käytetty regressiomalli selitti 12,9 \% kognitiivisesta kehityksestä 2-vuotiaana. Logaritmisen ymmärretyn sanaston standardoitu regressiokerroin $(\beta)$ oli 0.37 $(p=0.005)$. Syntymäpainon selitysaste ei ollut merkitsevä.

Vuoden korjatussa iässä eri sanaluokkakategorioihin kuuluvien ymmärrettyjen sanojen määrät sanastossa olivat tilastollisesti merkitsevässä, kohtuullisessa positiivisessa yhteydessä lapsen kahden vuoden iän kognitiivisen kehitykseen (Taulukko 5). Vahvin korrelaatio oli ymmärrettyjen substantiivien määrän ja myöhemmän kognitiivisen kehityksen välillä. Prosentuaalisista osuuksista vain sosiaalispragmaattisten sanojen, sulkeisen luokan sekä niin kutsuttujen muiden sanojen osuudet olivat tilastollisesti merkitsevästi yhteydessä kahden vuoden korjattuun kognitiiviseen kehitykseen (Taulukko 5). Sosiaalispragmaattisten sanojen osuus ja kognitiivisen standardipisteen välinen korrelaatio oli negatiivinen. Toisin sanoen suuri sosiaalispragmaattisten sanojen osuus varhaisessa ymmärretyssä sanastossa lisäsi riskiä myöhempään heikkoon kognitiiviseen kehitykseen. 
Kuvio 2. Pikkukeskosena syntyneiden lasten vuoden korjatussa iässä omaksumien ymmärrettyjen sanojen ja kahden vuoden iän kognitiivisen kehityksen välinen yhteys.

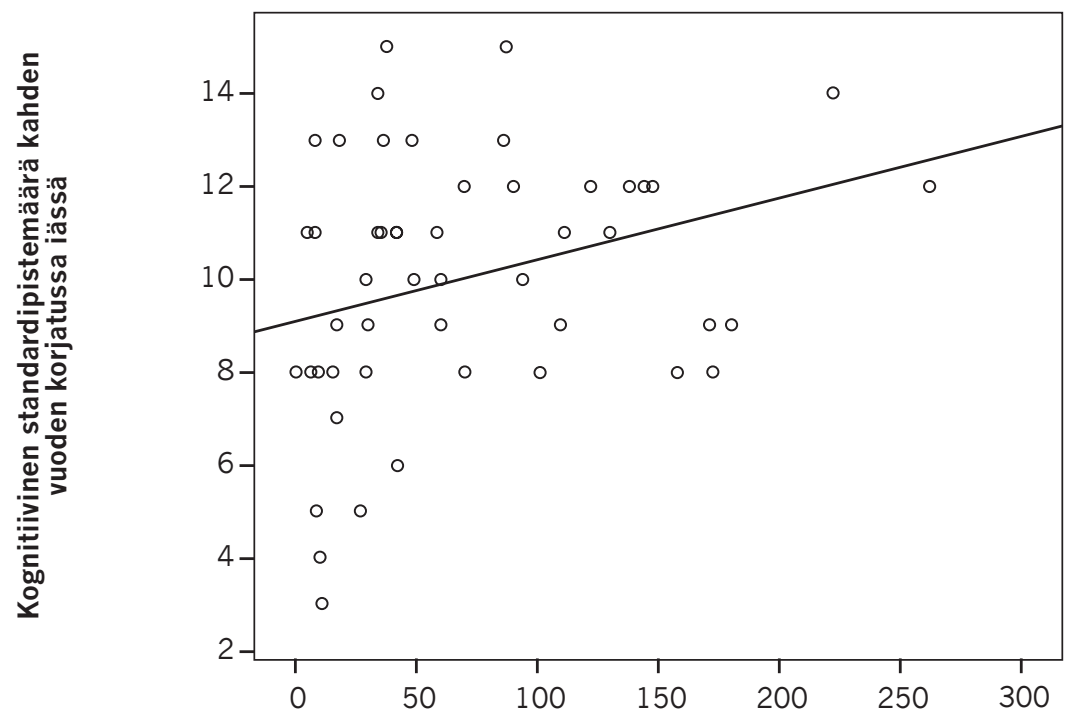

Ymmärrettyjen sanojen kokonaismäärä vuoden korjatussa iässä

Taulukko 5. Pikkukeskosena syntyneiden lasten vuoden iän ymmärrettyyn sanastoon sisältyneiden eri sanaluokkakategorioihin kuuluvien sanojen määrän ja prosentuaalisten osuuksien yhteys kahden vuoden iän kognitiivista kehitystä kuvaavaan standardipistemäärään. Taulukossa ilmoitetaan yhteyksiä kuvaavat Spearmannin korrelaatiokertoimet ( $r$ ) sekä merkitsevyystaso (p). Merkitsevät yhteydet on merkitty tummennetulla fontilla.

\begin{tabular}{|l|c|c|c|c|}
\hline & \multicolumn{3}{|c|}{$\begin{array}{c}\text { Sanamäärän yhteys } \\
\text { kognitiviseen kehitykseen }\end{array}$} & $\begin{array}{c}\text { Prosentuaalisten osuuksien } \\
\text { yhteys kognitiiviseen } \\
\text { kehitykseen }\end{array}$ \\
\hline \multicolumn{1}{|c|}{} & $r$ & $p$ & $r$ & $p$ \\
\hline Sosiaalis-pragmaattiset sanat & 0,28 & $\mathbf{0 , 0 4}$ & $-0,32$ & $\mathbf{0 , 0 2}$ \\
\hline Substantiivit & 0,33 & $\mathbf{0 , 0 1}$ & 0,22 & 0,11 \\
\hline Verbit & 0,32 & $\mathbf{0 , 0 2}$ & 0,05 & 0,71 \\
\hline Adjektiivit & 0,27 & $\mathbf{0 , 0 4}$ & 0,21 & 0,12 \\
\hline Sulkeisen luokan sanat & 0,29 & $\mathbf{0 , 0 3}$ & 0,29 & $\mathbf{0 , 0 3}$ \\
\hline Muut sanat & 0,29 & $\mathbf{0 , 0 3}$ & 0,27 & $\mathbf{0 , 0 4}$ \\
\hline
\end{tabular}


Kun varhaisen ymmärretyn sanaston ja myöhemmän kognitiivisen kehityksen yhteyttä tarkasteltiin jakamalla lapset alaryhmiin kahden vuoden iän kognitiivisen kehityksen perusteella, todettiin, että ne lapset, joiden kognitiivinen kehitys oli edennyt iänmukaisesti, olivat omaksuneet varhaisvaiheessa eniten ymmärrettyjä sanoja ( $\mathrm{ka}$ 73, kh 63 min. 0, maks. 262) kuin ne lapset, joilla oli lievä kognitiivinen viive (ka 24, kh 14, min. 9, maks. 42), tai ne lapset, joilla oli huomattava kognitiivisen kehityksen viive kaksivuotiaana (ka 11, kh 1, min. 10, maks. 11; Kuvio 3). Kaikki seitsemän kognitiiviselta kehitykseltään viiveistä lasta olivat poikia, he olivat syntyneet raskausviikoilla 27,4-31,9 ja heidän syntymäpainonsa vaihteli 1010-1985 g:n väliltä. Lapsista viidellä BAEB oli normaali, yhdellä poikkeava ja yhdeltä tietoa ei ollut saatavilla.

Kuvio 3.Pikkukeskosena syntyneiden lasten vuoden korjatussa iässä omaksuttujen ymmärrettyjen sanojen määrä suhteessa lapsen kognitiiviseen kehitykseen (normaali kehitys >8 standardipistettä, SP; lievä viive 6-7 SP; merkittävä viive 1-5 SP) kahden vuoden korjatussa iässä.

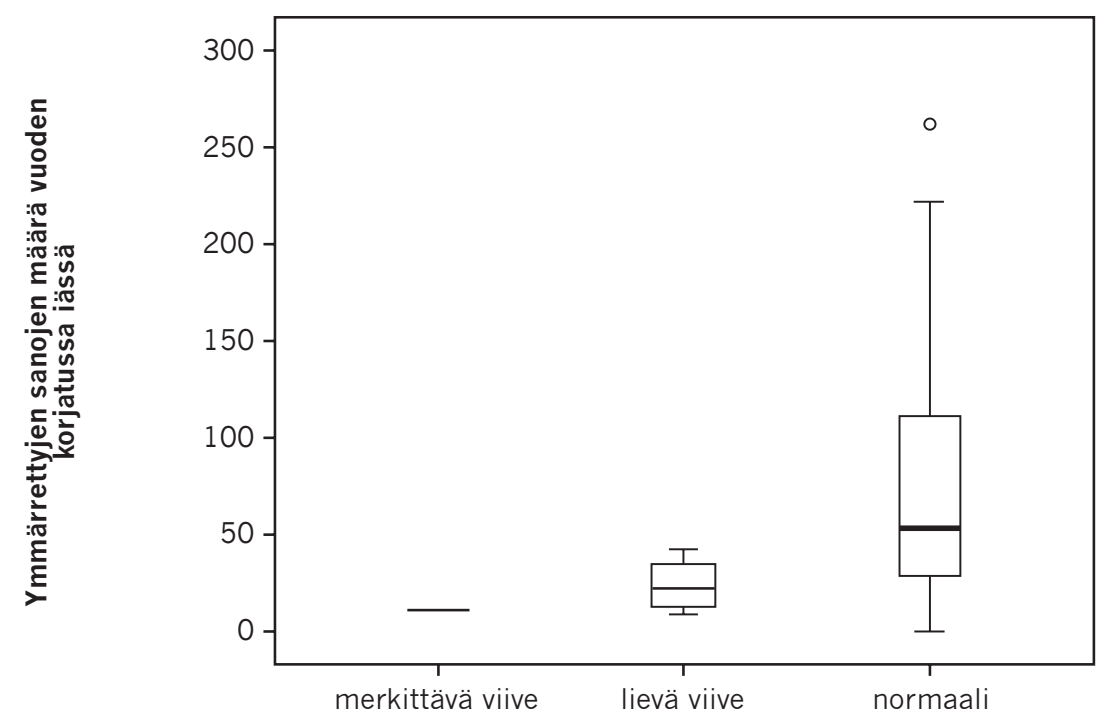

Kognitiivinen kehitys kahden vuoden korjatussa iässä

\section{POHDINTA}

Tämän tutkimuksen tavoitteena oli tutkia pikkukeskosena syntyneiden lasten ymmärretyn sanaston kokoa ja koostumusta vuoden korjatussa iässä. Lisäksi tutkittiin varhaisen ymmärretyn sanaston kehityksen mahdollista yhteyttä lasten kahden vuoden korjatussa iäs- sä arvioituun kognitiiviseen kehitykseen. Pikkukeskosena syntyneiden lasten varhaisen ymmärretyn sanaston koko oli selvästi pienempi kuin tutkimuksessa käytetyn menetelmän normiaineistossa. Myös selvästi suuremmalla osalla keskosista oli hyvin niukka ymmärretyn sanaston koko vuoden korjatussa iässä kuin käytetyn arviointimenetelmän normiaineis- 
tossa. Tarkasteltaessa ymmärretyn sanaston koostumuksen kehitystä suhteessa ymmärretyn sanaston määrälliseen kehitykseen todettiin koostumuksen kehityksen kuitenkin noudattavan aiemmin havaittuja kehityspolkuja (Caselli ym., 1995; Stolt ym., 2009). Pikkukeskosten varhaisen ymmärretyn sanaston kehityksellä oli merkitsevä positiivinen yhteys myöhempään kognitiiviseen kehitykseen.

Pikkukeskosten ymmärretyn sanaston keskimääräinen koko oli selvästi pienempi ja selvästi suuremmalla osalla pikkukeskosista oli hyvin niukka ymmärretyn sanaston koko vuoden korjatussa iässä käytetyn arviointimenetelmän normiaineistoon verrattuna (vrt. Lyytinen, 1999). Tulos on rinnasteinen aiempien keskostutkimusten löydösten kanssa (Cattani ym., 2010; Sansavini ym., 2011; Stolt ym., 2009). Tulokset vahvistavat näkemystä siitä, että pikkukeskosena syntyneiden lasten ryhmään sisältyy täysiaikaisena syntyneitä lapsia useammin sellaisia lapsia, joilla kielenkehitys etenee keskimääräistä hitaammin. Tuloksia tulkittaessa on tärkeää ottaa huomioon huomattava yksilöiden välinen variaatio. Tässäkin tutkimuksessa oli mukana pikkukeskosia, joiden ymmärretyn sanaston koko vastasi normiaineiston tyypillistä tai keskimääräistä parempaa ymmärretyn sanaston kokoa. Hitaampaa varhaisen ymmärretyn sanaston kehitystä ei siis voida yleistää koskemaan kaikkia pikkukeskosena syntyneitä lapsia.

Saadut tulokset vahvistavat näkemystä siitä, että vaikka ymmärretyn sanaston koostumus kehittyy keskosilla ryhmätasolla hitaammin kuin täysiaikaisena syntyneillä, koostumuksen kehitys näyttäisi kuitenkin olevan laadultaan samantyyppistä kummallakin ryhmällä, kun koostumuksen kehitystä tarkastellaan suhteessa sanaston kokoon (Stolt ym., 2009; ks. myös Sansavini ym., 2011). Tulokset vahvistavat myös näkemystä siitä, että verbejä omaksutaan varhaisiin ymmärrettyihin sanastoihin aktiivisesti (Caselli ym., 1995; Stolt ym., 2008). Tämän tutkimuksen löydökset antavat tärkeää tietoa varhaisen ymmärretyn sanaston kehityksestä, jota on aiemmin tutkittu vain vähän.

Pikkukeskosten vuoden iän ymmärretyn sanaston ja kahden vuoden iän kognitiivisen kehityksen välillä todettiin merkitsevä positiivinen yhteys ja vuoden iässä omaksuttujen ymmärrettyjen sanojen määrän havaittiin selittävän lähes $13 \%$ kahden vuoden iän kognitiivisen standardipistemäärän vaihtelusta. Vuoden korjatussa iässä mitattu suuri ymmärretyn sanaston koko ennakoi siis ryhmätasolla tarkastellen hyvää kognitiivista kehitystä korjatussa kahden vuoden iässä, ja pieni ymmärretyn sanaston kehitys vastaavasti heikkoa kognitiivista kehitystä. Tulos on kliinisesti mielenkiintoinen. Saatujen tulosten mukaan keskosten kielellistä ja kognitiivista kehitystä olisikin hyvä tarkastella kliinisessä työssä toisiinsa peilaten. Mikäli keskosen ymmärretty sanasto vaikuttaa kehittyvän hitaasti vuoden iässä, lisää se tämän tutkimuksen löydösten perusteella riskiä heikkoon myöhempään kognitiiviseen kehitykseen. Aiempia varhaisen ymmärretyn sanaston ja myöhemmän kognitiivisen kehityksen yhteyttä kartoittavia tutkimuksia keskosaineistossa ei juurikaan ole. Tämän tutkimuksen tulos on kuitenkin yhdenmukainen täysiaikaisena syntyneiden lasten aineistoissa raportoitujen löydösten kanssa (Laakso ym., 2011, Lyytinen, 1999). Tulos on myös yhdenmukainen aiempien ilmaistun sanaston ja kognitiivisen kehityksen välistä yhteyttä kartoittavien tutkimusten kanssa (Stolt ym., 2007; Mossabeb ym., 2012). Löydöksiä tulkittaessa on kuitenkin otettava huomioon se, että ilmaistu ja ymmärretty sanasto eivät kehity kaikilla lapsilla rinnakkain (Bates ym., 1995). Ilmaistun ja ymmärretyn sanaston kehitystä on siis tärkeää kartoittaa erikseen sekä tutkimuksessa että kliinisessä työssä.

Ymmärretyn sanaston koostumuksen yhteyttä kognitiiviseen standardipistemäärän 
tutkittiin sekä sanamäärien että prosentuaalisten osuuksien avulla. Eri semanttisiin sanaluokkakategorioihin kuuluneiden sanojen määrät vaikuttivat olevan herkempiä myöhemmän kognitiivisen kehityksen ennakoijia kuin prosentuaaliset osuudet. Semanttisten sanaluokkakategorioiden prosentuaaliset osuudet sanastossa antavat kuitenkin sanamääriä enemmän tietoa sanaston kehitysvaiheesta. Kliinisessä työssä tulisikin pyrkiä luomaan mahdollisimman hyvä kokonaiskäsitys lapsen ymmärretyn sanaston kehityksestä, sekä koosta että koostumuksesta. Esimerkiksi tämän tutkimuksen aineistoon kuuluvilla keskosilla vuoden korjatussa iässä mitattu runsas sosiaalispragmaattisten sanojen osuus vaikutti lisäävän riskiä heikkoon kognitiiviseen suoriutumiseen kaksivuotiaana, kun taas suuri sulkeiseen luokkaan sisältyvin sanojen osuus oli yhteydessä vahvaan kognitiiviseen suoriutumiseen vuotta myöhemmin.

Tässä tutkimuksessa pikkukeskosten saama keskimääräinen kognitiivinen standardipistemäärä vastasi ikäryhmän keskitasoa. Tulos on yhdenmukainen Munckin ym. (2010) tutkimuksen löydösten kanssa. Suomalaislasten on muutoinkin havaittu saavan keskimäärin noin yhden standardipisteen verran parempia pisteitä Bayley III testin kognitiivista kehitystä mittaavasta osiosta kaksivuotiaana amerikkalaisiin ikätovereihin verrattuna, mikä on hyvä ottaa huomioon tuloksia tulkittaessa (ks. Munck ym. 2010; Salo ym., 2008). Tämän rekisteritutkimuksen tulokset tukevat osaltaan näkemystä siitä, että pikkukeskosena Suomessa syntyneiden lasten kognitiivinen kehitys etenee ainakin kehityksen varhaisvaiheessa ryhmätasolla arvioiden hyvin.

Syntymäpaino ei ollut tilastollisesti merkitsevässä yhteydessä vuoden korjatussa iässä mitattuun ymmärretyn sanaston kokoon, koostumukseen eikä kahden vuoden korjatussa iässä mitattuun kognitiiviseen kehitykseen. Löydös on hieman yllättävä, sillä ai- emmat löydökset viittaavat siihen, että mitä varhaisemmilla raskausviikoilla ja/tai mitä pienipainoisempana keskonen on syntynyt, sitä todennäköisempiä ovat myös kognitiivisen kehityksen lisääntyneet haasteet (esim. Foulder-Hughes \& Cooke, 2003) ja ongelmat tai viiveet kielellisessä kehityksessä (ks. esim Stolt ym., 2009; Sansavini ym., 2011). Tämän tutkimuksen löydöstä saattaa selittää se, että tämän tutkimuksen otanta ei ollut täysin kattava: osa heikosti kehittyvistä lapsista on voinut jäädä aineistosta pois.

\section{LOPUKSI}

Tämän tutkimuksen tavoitteena oli saada lisää tietoa pikkukeskosena syntyneiden lasten varhaisen ymmärretyn sanaston kehityksestä ja tämän kehityksen yhteydestä lapsen myöhempään kognitiiviseen kehitykseen. Tulokset vahvistavat näkemystä siitä, että pikkukeskosena syntyneiden lasten ymmärretty sanasto kehittyy ryhmätasolla tarkastellen hitaammin kuin täysiaikaisina syntyneillä lapsilla. Löydökset vahvistavat myös näkemystä siitä, että pikkukeskosten ymmärretyn sanaston koostumus kehittyy säännönmukaisessa suhteessa määrällisen kehityksen kanssa vastaavalla tavalla kuin täysiaikaisenakin syntyneillä lapsilla. Pikkukeskosena syntyneiden lasten varhaisen ymmärretyn sanaston ja myöhemmän kognitiivisen kehityksen yhteyden välillä todettiin ryhmätasolla merkitsevä positiivinen yhteys. Löydös antaa lisää tietoa pikkukeskosten varhaiseen kliiniseen seurantatyöhön, erityisesti heikon kognitiivisen kehityksen varhaiseen tunnistamiseen.

\section{LÄHTEET}

Alatalo, P. (2015). Hyvin ennenaikaisina jal tai hyvin pienipainoisina syntyneiden lasten ymmärtävän sanaston kehitys vuoden iässä ja sen yhteys kognitiiviseen kehitykseen kak- 
sivuotiaana. Pro gradu -tutkielma. Oulun yliopisto, humanistinen tiedekunta, logopedia.

Bates, E., Dale, P. \& Thal, D. (1995). Individual differences and their implications for theories of language development. Teoksessa P. Fletcher \& B. MacWhinney (toim.), The Handbook of Child Language (s. 96-151). Oxford: Blackwell.

Bates, E., Marchman, V., Thal, D., Fenson, L., Dale, P., Reznick, S., Reilly, J. \& Hartung, J. (1994). Developmental and stylistic variation in the composition of early vocabulary. Journal of Child Language, 21, 85-123.

Bayley, N. (2006). BAYLEY-III. Bayley scales of infant and toddler development-käsikirja. Helsinki: Psykologien Kustannus Oy.

Benedict, H. (1979). Early lexical development: Comprehension and production. Journal of Child Language, 6, 183-200.

Blackmon, L. R., Batton, D. G., Bell, E. F., Denson, S. E., Engle, W. A., Kanto, W. P., ...Stark, A. (2004). Age terminology during the perinatal period. Pediatrics, 114 , 1362- 1364.

Bode, M. M., D Eugenio, D. B., Forsyth, N., Coleman, J., Cross, C. R., \& Gross, S. J. (2009). Outcome of extreme prematurity: A prospective comparison of 2 regional cohorts born 20 years apart. Pediatrics, 124, 866-874.

Caselli, C., Casadio, P. \& Bates, E. (1999). A comparison of the transition from first words to grammar in English and Italian. Journal of Child Language, 26, 69-111.

Caselli, M., Bates, E., Casadio, P., Fenson, J., Fenson, L., Sanderl, J. \& Weir, J. (1995). A cross-linguistic study of early lexical development. Cognitive Development, 10, 159-199.

Cattani, A., Bonifacio, S., Fertz, M., Iverson, J. M., Zocconi, E. \& Caselli, M. C. (2010). Communicative and linguistic development in preterm children: A longitudinal study from 12 to 24 months. International Journal of Language \& Communication Disorders, 45, 162-173.

Fenson, L., Dale, P. S., Reznick, J. S., Bates, E., Thal, D. J. \& Pethick, S. J. (1994). Variability in early communicative development. Monographs of the Society for Research in Child Development, 59, 1-173.

Fenson, L., Marchman, V. A., Thal, D. J., Dale, P. S., Reznick, J. S. \& Bates, E. (2007). MacArthur-Bates Communicative Development Inventories. User's quide and technigal manual (2. painos). Baltimore, MD: Paul H. Brookes Publishing.

Foulder-Hughes, L. A. \& Cooke, R. W. (2003). Motor, cognitive, and behavioural disorders in children born very preterm. Developmental Medicine and Child Neurology, 45, 97-103.

Laakso, M.-L., Eklund, K. \& Poikkeus, A.-M. (2011). Esikko. Lapsen esikielellisen kommunikaation ja kielen ensikartoitus. Jyväskylä: Niilo Mäki instituutti.

Lind, A., Korkman, M., Lehtonen, L., Lapinleimu, H., Parkkola, R., Matomaki, J., Haataja, L. and the PIPARI Study Group. (2011). Cognitive and neuropsychological outcomes at 5 years of age in preterm children born in the 2000s. Developmental Medicine and Child Neurology, 53, 256262.

Lyytinen, P. (1999). Varhaisen kommunikaation ja kielen kehityksen arviointimenetelmä. Jyväskylä: Niilo Mäki Instituutti.

Lyytinen, P. (2000). Varhainen leikki ja sen arviointi. Jyväskylä: Niilo Mäki Instituutti. Menyuk, P., Liebergott, J., Schultz, M., Chesnick, M. \& Ferrier, L. (1991). Patterns of early lexical and cognitive development in premature and full-term infants. Journal of Speech and Hearing Research, 34, 88-94.

Metsämuuronen, J. 2006. Tutkimuksen tekemisen perusteet ihmistieteissä. Helsinki: Methelp Ky. 
Mossabeb, R., Wade, K.C., Finnegan, K., Sivieri, E. \& Abbasi, S. (2012). Language development survey provides a useful screening tool for language delay in preterm infants. Clinical Pediatrics, 51, 638-644.

Munck, P., Haataja, L., Maunu, J., Parkkola, R., Rikalainen, H., Lapinleimu, H...the PIPARI Study Group. (2010). Cognitive outcome at 2 years of age in Finnish infants with very low birth weight between 2001 and 2006. Acta Pediatrica, 99, 359-366.

Munck, P., Niemi, P., Lehtonen, L., Lapinleimu, H., Haataja, L. \& the PIPARI Study Group. (2012). Stability of cognitive outcome from two to five years of age in verylow-birth-weight children. Pediatrics, 129 , 503-508.

Nurmi, J.-E., Ahonen, T., Lyytinen, H., Lyytinen, P., Pulkkinen, L. \& Ruoppila, I. (2006). Ihmisen psykologinen kehitys. Helsinki: WSOY.

Orton, J., Spittle, A., Doyle, L., Anderson, P. \& Boyd, R. (2009). Do early intervention programmes improve cognitive and motor outcomes for preterm infants after discharge? A systematic review. Developmental Medicine \& Child Neurology, 51, 851-859.

Perlovsky, L. (2013). Language and cognition - joint acquisition, dual hierarchy, and emotional prosody. Frontiers in Behavioral Neuroscience, 7, 1-3.

Pyhälä-Neuvonen, R., Nyman, A. \& Korja, R. 2017. Keskosen kognitiivinen ja psykososiaalinen kehitys kouluiässä. Kirjassa $S$. Stolt, A. Yliherva, V. Parikka, L. Haataja \& L. Lehtonen (toim.), Keskosen hoito ja kehitys (s. 223-232). Helsinki: Duodecim.

Riitesuo, A. (2000). A preterm child grows: Focus on speech and language during the first two years. Jyväskylä Studies in Education, Psychology and Social Research 164. Jyväskylä: Jyväskylän yliopisto.

Sajaniemi, N., Hakamies-Blomqvist, L., Mäkelä, J., Avellan, A., Rita, H. \& von Wendt,
L. (2001). Cognitive development, temperament and behavior at 2 years as indicative of language development at 4 years in preterm infants. Child Psychiatry and Human Development, 31, 329-348.

Salo, S., Munck, P., Korja, R. (2008). Bayley Scales of Infant and Toddler Development (3. laitos, suomalainen käsikirja). Helsinki: Psykologien Kustannus Oy.

Sansavini, A., Guarini, A., Savini, S., Broccoli, S., Justice, L., Alessandroni, R. Faldella, G. (2011). Longitudinal trajectories of gestural and linguistic abilities in very preterm infants in the second year of life. Neuropsychologia, 49, 3677-3688.

Stolt, S., Haataja, L., Lapinleimu, H. \& Lehtonen, L. (2008). Early lexical development of Finnish children: A longitudinal study. First Language, 28, 259-279.

Stolt, S., Haataja, L., Lapinleimu, H. \& Lehtonen, L. (2009). The early lexical development and its predictive value to language skills at 2 years in very-low-birth-weight children. Journal of Communication Disorders, 42, 107-123.

Stolt, S., Klippi, A., Launonen, K., Munck, P., Lehtonen, L., Lapinleimu, H., Haataja, L. \& PIPARI Study Group. (2007). Size and composition of the lexicon in prematurely born very-low-birth-weight and fullterm Finnish children at two years of age. Journal of Child Language, 34, 283-310.

Stolt, S., Matomäki, J., Lind, A., Lapinleimu, H., Haataja, L. \& Lehtonen, L. (2014a). The prevalence and predictive value of weak language skills in children with very low birth weight - a longitudinal study. Acta Paeditrica, 103, 651-658.

Stolt, S., Mäkilä, A.-M., Matomäki, J., Lehtonen, L., Lapinleimu, H. \& Haataja, L. (2014b). The development and predictive value of gestures in very-low-birth-weight children: A longitudinal study. International Journal of Speech-Language Pathology, 
16, 121-131.

Stolt, S., Savini, S., Guarini, A., Caselli, M., Matomäki, J., Lapinleimu, H., Haataja, L., Lehtonen, L., Alessandroni, R., Faldella, G. \& Sansavini, A. 2017. Does native language influence the lexical composition in very preterm children at 2;0? A cross-linguistic comparison study of Italian and Finnish children. First Language, 37, 368-390.

Toome, L., Varendi, H., Männamaa, M., Vals, M.-A., Tänavsuu, T. \& Kolk, A. (2013).
Follow-up study of 2-year-olds born at very low gestational age in Estonia. Acta Paediatrica, 102, 300-307.

Woodward, L. J., Anderson, P. J., Austin, N. C., Howard, K., \& Inder, T. E. (2006). Neonatal MRI to predict neurodevelopmental outcomes in preterm infants. The New England Journal of Medicine, 355, 685-694. 


\section{THE DEVELOPMENT OF RECEPTIVE LEXICON AT 1;0 AND ITS ASSOCIATION TO COGNITIVE DEVELOPMENT AT 2;0 IN VERY PRETERM OR VERY-LOW-BIRTH-WEIGHT CHILDREN}

Pauliina Alatalo, University of Oulu and HABS kuntoutus rehabilitering Oy

Petriina Munck, Turku University hospital and University of Helsinki

Helena Lapinleimu, Turku University hospital and University of Turku

Suvi Stolt, University of Helsinki

This study aimed to investigate the size and composition of the receptive lexicon in very preterm (VP; born at <32 gestational weeks) and/or very-low-birth-weight (VLBW; birth weight $<1500 \mathrm{~g}$ ) children at 1;0. The possible association between early receptive lexicon and cognitive development at 2;0 was also analysed. In this register study, all preterm children ( $\mathrm{N}=57$ ) were born in Turku University Hospital between 2007-2009. The methods used were the Finnish version of the MacArthur Communicative Development Inventory (FinCDI) and Bayley Scales of Infant Development III. The receptive lexicon size of the preterm children was smaller than the one of the norming sample of the FinCDI. On the group level, the composition of the receptive lexicon was comparable to that reported in previous studies. The early receptive lexicon size and composition correlated significantly and positively with later cognitive development. Results verify earlier reported findings on the smaller receptive lexicon at 1;0 in preterm children. Results also provide further, new information on the significant association between early receptive lexicon and later cognitive development in very preterm children. This information can be used in the clinical context when aiming to identify those children who need support for their development.

Keywords: cognitive development, lexicon composition, lexicon size, receptive lexicon, very-low-birth-weight, very preterm 